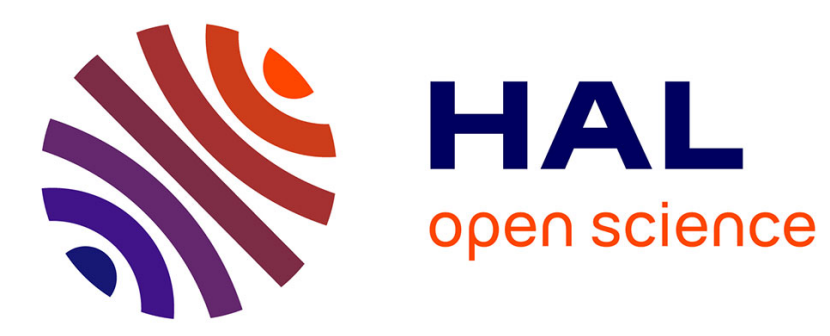

\title{
Restorative pulpal and repair responses
}

Peter Murray, Imad About, Jean-Claude Franquin, Mireille Remusat, Anthony Smith

\section{To cite this version:}

Peter Murray, Imad About, Jean-Claude Franquin, Mireille Remusat, Anthony Smith. Restorative pulpal and repair responses. Journal of the American Dental Association, 2001, 132 (4), pp.482-491. 10.14219/jada.archive.2001.0211 . hal-03552485

\section{HAL Id: hal-03552485 \\ https://hal.science/hal-03552485}

Submitted on 2 Feb 2022

HAL is a multi-disciplinary open access archive for the deposit and dissemination of scientific research documents, whether they are published or not. The documents may come from teaching and research institutions in France or abroad, or from public or private research centers.
L'archive ouverte pluridisciplinaire HAL, est destinée au dépôt et à la diffusion de documents scientifiques de niveau recherche, publiés ou non, émanant des établissements d'enseignement et de recherche français ou étrangers, des laboratoires publics ou privés.

\section{(이) $\$$}

Distributed under a Creative Commons Attribution - NonCommercial - NoDerivatives| 4.0 


\section{Restorative pulpal and repair responses}

\author{
PETER E. MURRAY, B.Sc., Ph.D.; IMAd ABOUT, \\ B.SC., Ph.D.; JEAN-CLAUDE FRANQUIN, D.SC. \\ Odont.; MIREILLE REMUSAT, B.SC.; ANTHONY J. \\ SMITH, B.Sc., Ph.D.
}

electing a restorative material and using it properly continues to be a source of frustration for many clinicians. Controversy surrounds the most suitable choice of restorative materials and placement methods that will result in the highest probability of successful treatment. Each year in the United States, 90 million new fillings are placed, ${ }^{1}$ and the placement of these materials will induce a response in the tooth dentin-pulpal complex to some degree..$^{2-6}$ In addition, some 200 million fillings are replaced each year in the United States. ${ }^{1}$ Evidently, there remains some potential to increase the longevity of restorations. Improvements may be achievable if the relationships between restora-

The results tive materials, pulpal responses and the show that reasons for failure are better understood.

bacterial However, few comparative clinical data are microleakage, available for commonly used restorative pulpal injury materials.

and repair

responses varied widely with different

restorative materials.

The choice of one type of restorative material over another can make the difference between success and failure within a few years. ${ }^{7-10}$ Various factors can account for the failure of restorations, such as tooth fracture, marginal fracture and degradation via abrasion, attrition, erosion and noncarious defects, as well as the patient's dental characteristics, diet and oral hygiene. ${ }^{7,8}$ Nevertheless, the most frequent ${ }^{9,10}$ and potentially serious postoperative complications can emanate from bacterial microleakage along the interface between the restoration and the tooth.

Microleakage complications include postoperative sensitivity, marginal discoloration, recurrent caries, pulpal inflammation, pulpal necrosis, periodontal disease and the eventual need for endodontic therapy. ${ }^{11,12}$
Background. Each year, about 90 million new restorations are placed in

the United States and 200

million are replaced.

Controversy surrounds

the pulpal reactions

and frequency of bacte-

rial microleakage asso-

ciated with common

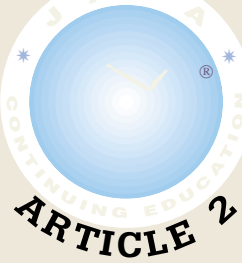

restorative materials. The authors investigated and compared pulpal reactions to different types of restorative materials.

Methods. Two hundred seventy-two teeth with standardized rectangular Class $\mathrm{V}$ unexposed cavities were restored with resin-based composite bonded to dentin; resin-based composite bonded to enamel; resin-modified glass ionomers, or RMGI; amalgam lined with zinc polycarboxylate, or ZnPC; amalgam lined with calcium hydroxide, or $\mathrm{Ca}(\mathrm{OH})_{2}$; or zinc oxideeugenol, or $\mathrm{ZnOE}$. Teeth were extracted for orthodontic reasons between 20 and 381 days later. The authors categorized pulpal responses according to standards set by the Federation Dentaire Internationale and the International Organization for Standardization. Bacteria were detected using Brown-Brenn-stained sections. Pulpal responses were evaluated using histomorphometric analysis and analysis of variance statistics.

Results. The results showed that RMGI was the best material for preventing bacterial microleakage, and resin-based composite bonded to enamel was the worst. In regard to minimizing pulpal inflammatory activity, $\mathrm{ZnOE}$ was the best material and resin-based composite bonded to enamel was the worst. In terms of maximizing odontoblast survival beneath deep cavity preparations, $\mathrm{Ca}(\mathrm{OH})_{2}$, was the best material and RMGI was the worst.

Conclusions. The results show that bacterial microleakage, pulpal injury and repair responses varied widely with different restorative materials.

Clinical Implications. The authors recommend that RMGI be used to restore teeth with cavities that are shallow to moderate in depth, with the floor of deep cavities being lined with $\mathrm{Ca}(\mathrm{OH})_{2}$ before the teeth are restored with RMGI. 


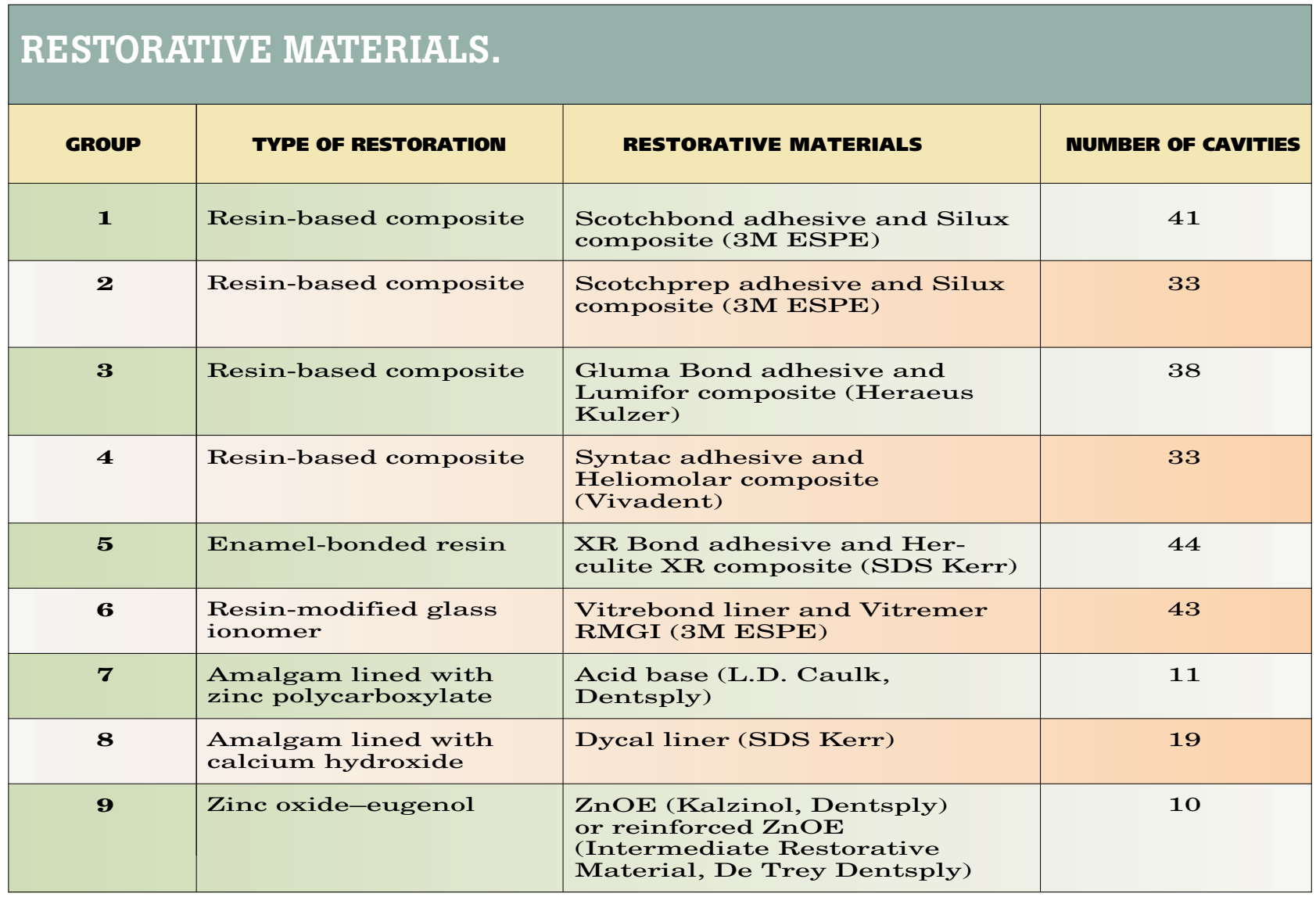

Unchecked microleakage complications can progress to development of periapical lesions and local bone destruction. ${ }^{13}$ Because of these complications, it is essential to examine the incidence of microleakage with commonly used restorative materials to understand how the choice of material can affect the development of pulpal injury, dentinal repair activity, inflammation and necrosis.

Resin-based composite restorations have increased in popularity because of their improved longevity, biocompatibility, antimicroleakage characteristics, wear resistance and ability to compare favorably with amalgam restorations. ${ }^{14-18}$

Moreover, resin-based composite restorations are more esthetically pleasing than amalgam restorations and have expanded the range of possibilities for restorative dentistry, allowing deteriorated or debonded restorations to be repaired or replaced with minimal loss of tooth structure. ${ }^{19}$ Large undercuts of vital tooth structure needed to retain the restoration usually are not necessary. ${ }^{20}$ Resin-based composite adhesive systems have been developed to bond to enamel, dentin, amalgam, metal and porcelain. However, some resin-based composite adhesive systems primarily adhere to enamel, and uncertainty remains about the benefits of these systems in comparison with dentin-bonded systems, particularly in terms of antimicroleakage characteristics. ${ }^{21}$

Restoration with other materials such as resinmodified glass ionomers, or RMGIs, also is gaining in popularity because of their ability to adhere to tooth surfaces and their fluoride-release activity, which can inhibit recurrent caries and promote remineralization..$^{22,23}$ These considerations, in addition to the disadvantages of liners such as zinc polycarboxylate, or ZnPC, and calcium hydroxide, or $\mathrm{Ca}(\mathrm{OH})_{2}{ }^{24}$ - especially their inability to provide an effective long-term antimicrobial protection against microleakage ${ }^{25}$ and health concerns about the potential effects of mercury release from amalgam ${ }^{26}$ - explain why clinicians are evaluating alternatives and placing more resin-based composite and RMGI restorations. ${ }^{16,27}$

Many aspects of restorative materials are critical to their success. However, quantitative comparisons between different types of commonly 
used restorative materials are sparse and, as a result, disparate claims often are made in regard to the postoperative effects of these materials. Consequently, the purpose of our study was to provide information about the incidence of bacterial microleakage, the severity of pulpal inflammation, the density of odontoblasts remaining beneath cavity preparations (which are critical to maintaining pulpal vitality ${ }^{28}$ and tertiary dentinal repair activity associated with commonly used restorative materials.

\section{SUBJECTS, MATERIALS AND METHODS}

Subjects consisted of 135 healthy patients ( 86 female [63.7 percent] and 49 male [36.3 percent]), with a mean age of 12.54 years and an age range between 9 and 25 years. Clinicians prepared Class V cavities in 272 noncarious intact first or second maxillary or mandibular premolars, which were scheduled for extraction for orthodontic reasons. Teeth were extracted in Marseille Hospital dental care centers, Marseille, France, between three and 364 days after restorations were placed (mean time, 68.45 days) with the use of a local anesthetic and after patient and parental informed consent was obtained.

The standardized methods and procedures used in this study have been described elsewhere. ${ }^{2,28,29}$ Briefly, clinicians placed Class V cavity preparations in the buccal surface of teeth, 1 millimeter above the level of the cementoenamel junction. Preparation forms were cut into the tooth dentin using the least possible pressure at a drill speed of 400,000 revolutions per minute with water spray coolant. Cavity dimensions were estimated during cutting; however, a histometric analysis of the histologic sections found that the cavities were cut into dentin to a range of remaining dentin thicknesses, or RDTs (between the cavity floor and the pulpal tissue) between 0.040 and $2.993 \mathrm{~mm}$ (mean thickness, $0.90 \mathrm{~mm}$ ) and axial floor widths between 0.99 and $3.17 \mathrm{~mm}$ (mean width, $1.86 \mathrm{~mm}$ ).

We assigned teeth to nine experimental groups for restoration (Table 1). All of the products were used in strict accordance with the manufacturers' instructions.
Group 1. Clinicians etched enamel and dentin cavity walls with 37 percent phosphoric acid gel. The gel was left in place for 60 seconds and the teeth then were rinsed for 30 seconds with water. This was followed by air-drying for 20 seconds. Adhesive primer (Scotchbond, 3M ESPE) was applied to the cavity walls with the brush supplied for the purpose. The cavity then was dried for 30 seconds to remove alcohol from the primer's resin. This procedure was repeated to apply a second coating of adhesive primer. Clinicians then filled the cavity with a resin-based composite mixture (Silux, 3M ESPE) and polymerized it with a curing light for 40 seconds.

Group 2. Clinicians placed resin-based composite restorations using identical procedures as those above, except Scotchprep adhesive (3M ESPE) was used in place of Scotchbond.

Group 3. After cavity preparation, clinicians applied 17 percent ethylenediaminetetraacetic acid (Dentin conditioner, 3M ESPE) to the cavity walls for 30 seconds. Two coatings of adhesive (Gluma Bond, Heraeus Kulzer) then were applied, interspersed with a drying time of 30 seconds for each. Resin-based composite (Lumifor, Heraeus Kulzer) then was placed. The composite was light-polymerized for 40 seconds.

Group 4. Cavity walls were prepared and etched with phosphoric acid according to the same procedures followed in groups 1 and 2, except that Syntac adhesive (Vivadent) was applied before the cavity was filled with resin-based composite (Heliomolar, Vivadent).

Group 5. Clinicians etched enamel with 37 percent phosphoric acid gel, which was left in place for 60 seconds and then rinsed off with water for 30 seconds. This was followed by 20 seconds of air-drying. Two coatings of adhesive (XR Bond, SDS Kerr) were applied and allowed to dry for 30 seconds each, before the cavity was filled with enamel-bonded resin (Herculite XR, SDS Kerr).

Group 6. Cavities were conditioned with 37 percent phosphoric acid gel, as described above, before the teeth were restored with RMGI liner (Vitrebond, 3M ESPE) and RMGI (Vitremer, 3M ESPE). 
Groups 7 and 8. Clinicians lined amalgam restorations with either a $\mathrm{ZnPC}$ cement (L.D. Caulk, Dentsply) or $\mathrm{Ca}(\mathrm{OH})_{2}$ liner (Dycal, SDS Kerr).

\section{TABLE 2}

\section{PUIPAIL INFIAMMMATORY ACIIVITY AND PRESENCE OF BACIHRTA IN RESIORAIIONS.}

\begin{tabular}{|c|c|c|c|c|c|}
\hline \multirow[t]{3}{*}{ RESTORATIVE MATERIAL } & \multicolumn{3}{|c|}{$\begin{array}{l}\text { PULPAL INFLAMMATION, } \\
\text { PERCENTAGE OF TEETH }\end{array}$} & \multirow{2}{*}{\multicolumn{2}{|c|}{$\begin{array}{l}\text { BACTERIA } \\
\text { IN CUT } \\
\text { DENTINAL } \\
\text { TUBULES, } \\
\text { PERCENTAGE } \\
\text { OF TEETH }\end{array}$}} \\
\hline & \multirow{2}{*}{$\begin{array}{l}\text { Absent/ } \\
\text { Slight }\end{array}$} & \multirow[t]{2}{*}{ Moderate } & \multirow[t]{2}{*}{ Severe } & & \\
\hline & & & & No & Yes \\
\hline $\begin{array}{l}\text { Resin-Based } \\
\text { Composite } \\
\text { Bonded to Dentin }\end{array}$ & 32 & 59 & 9 & 89 & 11 \\
\hline $\begin{array}{l}\text { Resin-Based } \\
\text { Composite } \\
\text { Bonded to Enamel }\end{array}$ & 38 & 56 & 6 & 76 & 24 \\
\hline $\begin{array}{l}\text { Resin-Modified } \\
\text { Glass Ionomer }\end{array}$ & 51 & 49 & $\mathbf{O}$ & 100 & $\mathbf{O}$ \\
\hline $\begin{array}{l}\text { Zinc } \\
\text { Oxide-Eugenol }\end{array}$ & 91 & 9 & $\mathbf{O}$ & 100 & $\mathbf{O}$ \\
\hline $\begin{array}{l}\text { Calcium } \\
\text { Hydroxide }\end{array}$ & 83 & 17 & $\mathbf{O}$ & —* & - \\
\hline $\begin{array}{l}\text { Zinc } \\
\text { Polycarboxylate }\end{array}$ & - & - & - & - & - \\
\hline
\end{tabular}

Group 9. Clinicians restored teeth with zinc oxide-eugenol, or ZnOE (Kalzinol, Dentsply) or a reinforced $\mathrm{ZnOE}$ product (Intermediate Restorative Material, De Trey Dentsply).

Extracted teeth. We prepared extracted teeth for light microscopy and conducted a histomorphometric analysis, as described previously. ${ }^{28,29}$ Briefly, 5micrometer tooth sections were stained with hematoxylin and eosin, the area of tertiary dentin was estimated histomorphometrically at $\times 100$ magnification with the use of a grid eyepiece graticule, and the RDT was measured. Odontoblasts with a distinct nuclei and intact cytoplasm were counted beneath the cavity preparations per square millimeter unit of pulpal area, as well as the odontoblasts per square millimeter opposite and independent of the cavity preparation. . $^{28,30}$

Pulpal inflammation. We categorized pulpal inflammatory responses as absent/slight, moderate or severe, on the basis of published criteria ${ }^{2,28,29}$ and standards set by the Federation Dentaire Internationale ${ }^{31}$ and Interna-

\section{TABLE 3}

\section{HIERARCHY OF VARIABIES IN REIAHON TO THRTIARY DENTIN REPAIR ACIIVITY AND ODONTOBIAST DENSITY BENEATH CAVITY PREPARATIONS.}

\begin{tabular}{|c|c|c|}
\hline \multirow[t]{2}{*}{ VARIABLE } & \multicolumn{2}{|c|}{ P VALUE USING ANOVA* } \\
\hline & $\begin{array}{l}\text { Tertiary Dentin Area } \\
\text { Beneath Cavity } \\
\text { Preparations }\end{array}$ & $\begin{array}{l}\text { Odontoblast Density } \\
\text { Beneath Cavity } \\
\text { Preparations }\end{array}$ \\
\hline Remaining Dentin Thickness & .0001 & .0001 \\
\hline Type of Restorative Material & .0012 & .0354 \\
\hline Cavity Etching & .0043 & .5663 \\
\hline Time Elapsed Since Surgery & .0087 & .3215 \\
\hline $\begin{array}{l}\text { Bacteria in Cut Dentinal } \\
\text { Tubules }\end{array}$ & .0093 & .0906 \\
\hline Pulpal Inflammatory Activity & .6930 & .0005 \\
\hline
\end{tabular}




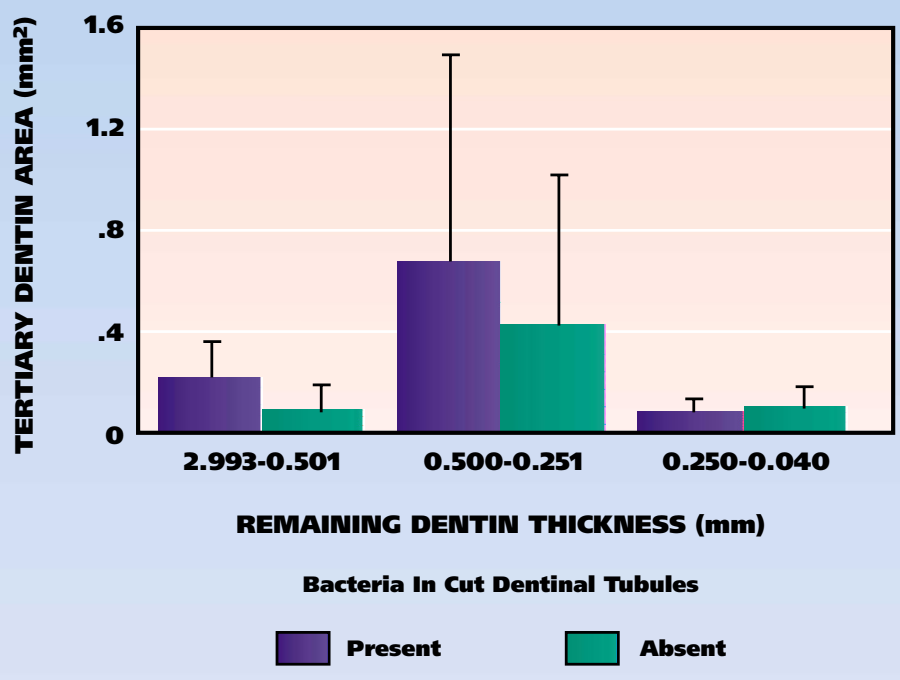

Figure 1. Tertiary denin area and remaining dentin thickness.

tional Organization for Standardization. ${ }^{32}$ In addition to other distinguishable pathological features, a severe response indicated that the pulpal tissue was largely necrotic, and the odontoblasts beneath the cavity floor were completely disintegrated. A moderate response indicated a reduction in the number of odontoblasts, the presence of localized inflammatory lesions, and tissue infiltration of polynuclear lymphocytes or polynuclear leukocytes. Absent or slight inflammatory responses indicated that the odontoblast layer appeared normal. Bacterial contamination of the restorations, or of the underlying dentinal tubules, was assessed with the Brown-Brenn procedure $^{33}$ for determining the presence of grampositive and gram-negative bacteria. The raw numerical data were examined with analysis of variance, or ANOVA (StatView software, SAS Inc.).

\section{RESULTS}

Bacterial microleakage. The Brown-Brenn procedure identified small or medium quantities of bacteria in 12.12 percent of restored teeth. The ability of restorative materials to prevent microleakage of bacteria into cut dentinal tubules varied, as shown in Table 2. Overall, we found that the selection of restorative material was important in preventing bacterial microleakage of the cavity preparations (ANOVA, $P=.020$ ).

The presence of bacteria within the cut dentinal tubules of cavities appeared to influence tertiary dentin repair activity (Table 3 ). We found that the mean area of tertiary dentin beneath a cavity preparation with an RDT between 2.993 and $0.501 \mathrm{~mm}$ was 235.9 percent greater in the presence of bacterial microleakage than the mean area in uncontaminated preparations (Figure 1). A similar comparison of cavities with an RDT between 0.500 and $0.251 \mathrm{~mm}$ showed that the area of tertiary dentin increased by 60.4 percent in the presence of bacterial microleakage. However, once the RDT was reduced to between 0.250 and $0.040 \mathrm{~mm}$, the effect of bacterial microleakage did not appear to have much influence on tertiary dentin activity ( -6.2 percent) in comparison with uncontaminated cavity preparations.

Pulpal inflammatory activity. We did not find any correlation between pulpal inflammatory activity and the area of tertiary dentin secretion (Table 3). Severe pulpal inflammatory activity was categorized according to pulpal necrosis and odontoblast injury. The severity of pulpal inflammatory activity appeared to result from the bacterial infiltration into cut dentinal tubules beneath cavity preparations (ANOVA, $P=.0006$ ). Severe forms of pulpal inflammation were observed after bacterial microleakage within resin-based composite restorations that were bonded to enamel and dentin (Table 2). No bacterial microleakage was detected in any of the RMGI or $\mathrm{ZnOE}$ restorations, and these restorations did not appear to be associated with severe pulpal inflammatory activity (Table 2).

Tertiary dentin activity. A histomorphological evaluation of the extracted premolar specimens revealed the presence of a tertiary dentin matrix beneath 52.7 percent of all restorations. In all cases, a tubular continuity was maintained between the secondary dentin matrix and the preexisting odontoblasts. These observations led us to classify the secreted tertiary dentin matrix as reactionary ${ }^{28,29}$ (reparative) in origin, and, consequently, our observations of tertiary dentin activity should not be confused with dentin bridge formation, which is an entirely different form of dentin repair activity.

We observed the RDT of cavity preparations to be a more powerful stimulus for the initiation and progression of a tertiary dentinogenic response than any of the other cavity cutting and restoration variables (Table 3). Maximal tertiary dentin deposition was found to take place when the RDT was between 0.500 and $0.251 \mathrm{~mm}$, while cavities cut with an RDT of less than $0.251 \mathrm{~mm}$ or more 
than $0.500 \mathrm{~mm}$ appeared to result in more minimal tertiary dentin deposition (Figure 1).

Although tertiary dentin area was found to be influenced by the presence or absence of cavityetching procedures, as well as by the time elapsed since surgery (Table 3), the type of restorative material was found to be of relatively greater importance (Table 3). The order of tertiary dentin deposition, from greatest to lowest, was as follows (using the mean area with calcium hydroxide as a standard baseline for comparison): $\mathrm{Ca}(\mathrm{OH})_{2}(100$ percent), resin-based composite bonded to dentin (68.8 percent), resin-based composite bonded to enamel (46.9 percent), RMGI (39.1 percent), $\mathrm{ZnOE}$ (20.5 percent) and $\mathrm{ZnPC}$ (0 percent)

(Figure 2).

Odontoblasts. We found that the number of odontoblasts per square millimeter decreased in density beneath cavity preparations, with the RDT being the most important influence (Table 3 ). The general trend after restoration with all materials was for the mean odontoblast density to decrease by 24.3 percent for those preparations with an RDT between 0.500 and $0.251 \mathrm{~mm}$, in comparison with cavity preparations with an RDT between 2.993 and $0.501 \mathrm{~mm}$ (Figure 3). Deeper cavity preparations-that is, those with an RDT between 0.250 and $0.040 \mathrm{~mm}$-were found to have 30.5 percent fewer odontoblasts per square millimeter than cavity preparations with an RDT between 0.500 and $0.251 \mathrm{~mm}$ (Figure 3).

An important influence on the number of odontoblasts per square millimeter beneath cavity preparations was the type of material used to restore the teeth (Table 3). The hierarchy of materials in order of reduced odontoblast density between areas independent of the cavity and beneath cavities with an RDT between 0.250 and $0.040 \mathrm{~mm}$ is as follows (with reductions in parentheses): $\mathrm{Ca}(\mathrm{OH})_{2}$ (- 11.3 percent), $\mathrm{ZnOE}(-29.1$ percent), resin-based composite bonded to dentin (- 32.6 percent), ZnPC (-36.5 percent), resinbased composite bonded to enamel ( -55.2 percent) and RMGI (- 62.5 percent) (Figure 4).

Analysis of the RDT within groups to ensure valid comparisons. To eliminate the possibility of a mismatch of RDTs between each of the restoration variables, we measured the RDTs and compared them with each other using ANOVA statistics. No significant differences were observed at the $P=.05$ significance level for bacteria in tubules beneath restorations, acid etching, pulpal inflammation or types of

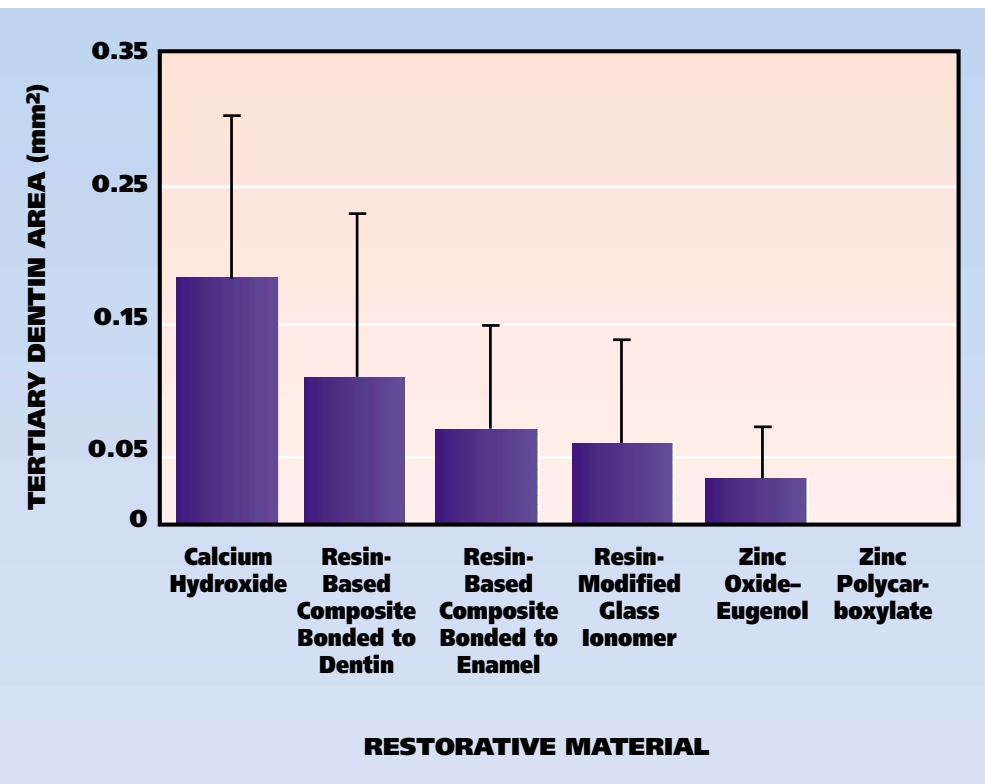

Figure 2. Tertiary dentin area beneath cavity preparations.

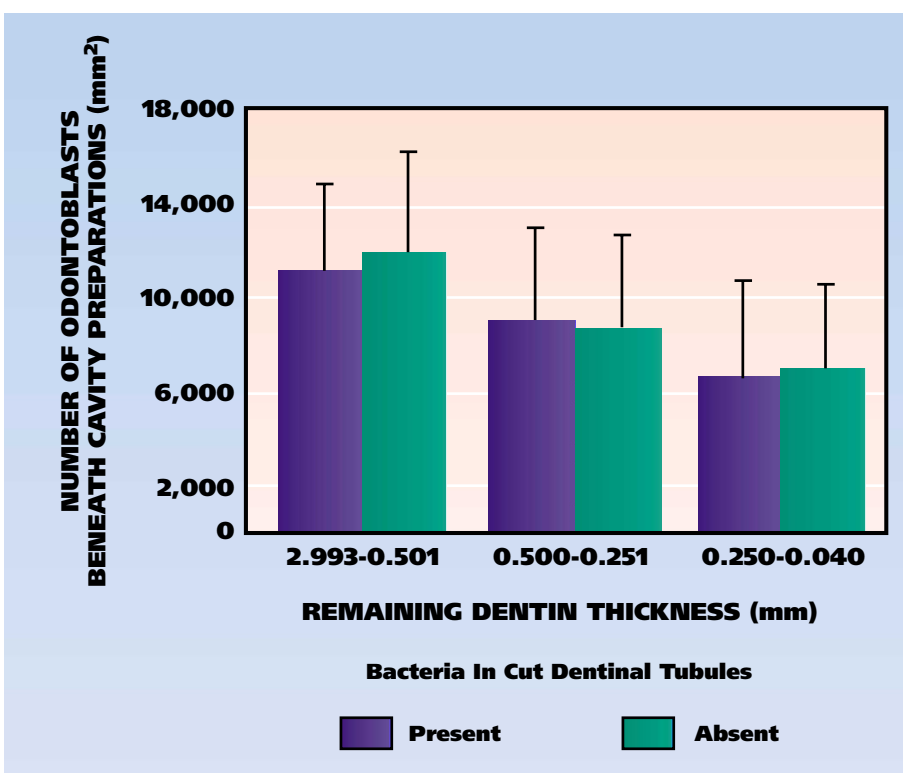

Figure 3. Odontoblast density and remaining dentin thickness.

restorative materials used.

\section{DISCUSSION}

The objective of having one type of restorative material that is suitable for every type of cavity preparation in all circumstances appears unlikely to be achieved in the near future. Consequently, researchers need to evaluate different types of materials clinically and compare them with each other. For this reason, we have attempted to 


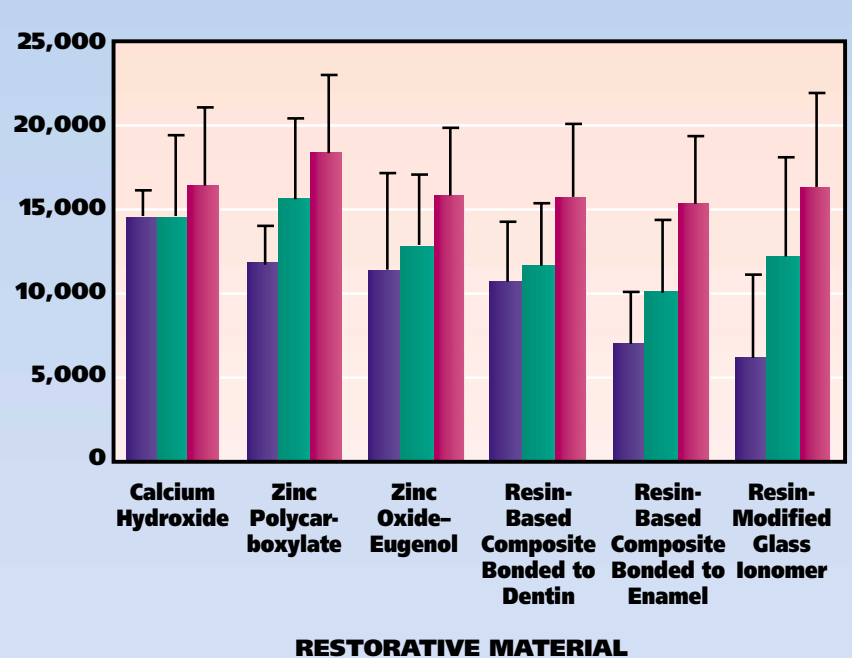

$\square$ Beneath a Remaining Dentin Thickness of 0.040 to $0.500 \mathrm{~mm}$

Beneath a Remaining Dentin Thickness of 0.501 to $2.993 \mathrm{~mm}$

$\square$ Independent of Cavity

Figure 4. Odontoblast density beneath cavity preparations.

examine postoperative pulpal responses to different types of restorative materials. However, the mechanical failure and leakage aspects of these materials, as well as unresolved pulpal injury requiring endodontic treatment, can take years to become apparent to patients, and we need to be cautious when interpreting results.

Nevertheless, the time elapsed between treatment and histometric analysis of teeth in our study was between 28 and 381 days. Evidence shows that tertiary dentin and odontoblast activity can be accomplished once 28 days have elapsed, ${ }^{28,29}$ and pulpal reactions to cavity preparation trauma can subside after about three weeks. ${ }^{34}$ Consequently, sufficient time had elapsed in our study to observe a comprehensive level of tertiary dentin repair activity and odontoblast responses. Moreover, sufficient time had elapsed to avoid the inclusion of transient pulpal inflammatory activity resulting from cavity preparation trauma. Our observations of pulpal inflammatory activity, therefore, are likely to be a result of the presence of restorative materials and microleakage of bacteria.

Severe inflammatory activity injures the pulpal cell populations, reducing pulpal vitality and, in the most severe cases, causing necrosis and obliteration of the whole tooth pulp. Our observations of severe pulpal inflammatory activity appear to correlate with the microleakage of bacteria into dentinal tubules. Resin-based composite restorations bonded to dentin or enamel had a 9 and 6 percent incidence, respectively, of severe pulpal inflammation, and an 11 and 24 percent incidence, respectively, of bacterial microleakage (Table 2). In contrast, RMGI and $\mathrm{ZnOE}$ restorations appear to have a zero incidence of bacterial microleakage and no observations of severe pulpal inflammation (Table 2).

The ability of RMGI and $\mathrm{ZnOE}$ to prevent microleakage may be attributed to the antibacterial activity of fluoride and eugenol release, in addition to their ability to form a good seal with cavity walls. ${ }^{35-38}$ On the other hand, the incidence of microleakage with resin-based composites may be attributed to their sealing and adhesion characteristics with cavity walls in addition to an absence of antibacterial activity. ${ }^{24}$ These histologic observations in regard to resin-based composites explain the 25 and 17 percent clinical failure rates reported after 11 years ${ }^{39}$ and seven years, respectively. ${ }^{40}$

The main shortcomings of resin-based composites are marginal defects and gaps, caused by the polymerization shrinkage of the resin during placement. Although sandwich placement techniques have been introduced, they are imperfect and operator-sensitive. ${ }^{38}$ For these reasons, new adhesive products are becoming available that will simplify the restorative process, thereby reducing the impact of sensitivity to operator handling. These developments in regard to resinbased composites may improve their antimicroleakage performance.

The higher frequency of bacterial microleakage associated with enamel bonding is related to the fact that the resin-based composite is bonded to tooth enamel and not to the dentin cavity surface. We had insufficient tooth material to stain $\mathrm{Ca}(\mathrm{OH})_{2}$ and $\mathrm{ZnPC}$ histologic sections for the presence of bacteria. However, in a study of primates in which restorations were in place between three and 97 days, Cox and colleagues ${ }^{38}$ observed bacteria in 9.4 percent of $\mathrm{Ca}(\mathrm{OH})_{2}$-lined amalgam restorations. The reasons for this high frequency of infection are the inability of $\mathrm{Ca}(\mathrm{OH})_{2}$ to completely seal with cavity walls, a lack of sustained antibacterial activity and poor physical characteristics. ${ }^{24,41}$ The continued use of $\mathrm{Ca}(\mathrm{OH})_{2}$ restorative materials is controversial, ${ }^{42}$ and observations of poor marginal sealing can have negative consequences in terms of the 


\section{ODONIOBIASI AND IHRIIARY DENIIN REPAIR RESPONSES TO DIFFERENT REMAMNING DENTIN THICKNESSES.}

\begin{tabular}{|c|c|c|c|c|}
\hline VARIABLE & $\begin{array}{l}\text { RESPONSE TO } \\
\text { SHALLOW } \\
\text { CAVITY RDT*† }\end{array}$ & $\begin{array}{c}\text { RESPONSE TO } \\
\text { DEEP CAVITY } \\
\text { RDT* }\end{array}$ & $\begin{array}{l}\text { RESPONSE TO } \\
\text { VERY DEEP } \\
\text { CAVITY RDTS }\end{array}$ & $\begin{array}{l}\text { PULPAL } \\
\text { EXPOSURE** }\end{array}$ \\
\hline $\begin{array}{l}\text { Odontoblast } \\
\text { Density } \\
\text { Beneath } \\
\text { Cavity } \\
\text { Preparations }\end{array}$ & $\begin{array}{l}100 \% \\
\text { (baseline) }\end{array}$ & $-24.3 \%$ & $-30.5 \%$ & $\begin{array}{l}\text { Almost } \\
100 \% \\
\text { loss }\end{array}$ \\
\hline $\begin{array}{l}\text { Tertiary } \\
\text { Dentin } \\
\text { Secretion }\end{array}$ & $\begin{array}{l}\text { +Bacteria, }{ }^{\dagger \dagger} \\
\text { 100\% } \\
\text { (baseline) } \\
\text { - Bacteria, } \\
\text { 40.5\% }\end{array}$ & $\begin{array}{l}\text { +Bacteria, } \\
341 \% \\
\text {-Bacteria, } \\
\mathbf{4 4 5 \%}\end{array}$ & $\begin{array}{l}+ \text { Bacteria, } \\
84 \% \\
- \text { Bacteria, } \\
66 \%\end{array}$ & $\begin{array}{l}\text { Dentin } \\
\text { bridge } \\
\text { formation }\end{array}$ \\
\hline \multicolumn{5}{|c|}{$\begin{aligned} * & \text { RDT: Remaining dentin thickness. } \\
\dagger & 2.993 \mathrm{millimeters} \text { to } 0.501 \mathrm{~mm} . \\
\ddagger & 0.500 \mathrm{~mm} \text { to } 0.251 \mathrm{~mm} . \\
\S & 0.250 \mathrm{~mm} \text { to } 0.040 \mathrm{~mm} \text {. } \\
* * & \text { No pulpal exposure data presented. } \\
\dagger & \text { + Bacteria: Bacterial microleakage detected in the cavity. } \\
\dagger & \text { - Bacteria: No bacterial microleakage detected in the cavity. }\end{aligned}$} \\
\hline
\end{tabular}

longevity of these restorations. ${ }^{42}$

We have shown that pulpal inflammation is correlated to bacterial microleakage, and the incidence of microleakage is correlated to specific restorative materials. However, the relationships between cavity RDT, odontoblast density and tertiary dentin repair activity require a more complex explanation, which we have shown schematically in Table 4.

Acid-etching and primer impregnation of vital dentin cavity walls to place resin-based composite restorations has been considered problematic, since researchers have thought it would increase the likelihood of pulpal injury ${ }^{43-45}$ by facilitating the penetration of irritants into cut dentinal tubules. ${ }^{45-47}$ However, our observations of pulpal injury show that resin-based composite restorations bonded to dentin are not associated with greater reductions in underlying odontoblast density than is unetched dentin in $\mathrm{ZnPC}$ or resinbased composite restorations bonded to enamel. The lack of pulpal injury associated with acidetching of vital dentin confirms that the findings from earlier primate studies $\mathrm{s}^{48,49}$ are applicable to the clinical situation in humans.

In our study, tertiary dentin repair activity appeared to be mediated by the RDT of cavity preparations. Previously, we reported that the tertiary (reactionary) dentin area increases in a linear manner with decreasing RDT, ${ }^{29}$ as well as with other variables. This linear concept remains a useful guide for predicting and estimating the area of tertiary dentin after restoration when the $\mathrm{RDT}$ is greater than $0.25 \mathrm{~mm}$.

However, our observations of poor tertiary dentin repair activity with RDTs between 0.250 and $0.040 \mathrm{~mm}$ (Figure 1) probably result from impaired odontoblast dentin secretory activity, resulting from cellular injury. In support of this theory, the mean number of intact odontoblasts found beneath the cavity preparation was 30.5 percent lower than the number found beneath similar preparations with an RDT between 0.500 and $0.251 \mathrm{~mm}$ (Figure 3). This lack of ability of odontoblasts to provide adequate pulpal repair and pulpal protection after deep cavity cutting is supported by Hebling and colleagues ${ }^{35}$ observations of a persistent inflammatory pulpal response following cavity cutting with RDTs of less than $0.3 \mathrm{~mm}$. In accordance with our previous observations, ${ }^{29}$ when the cavity RDT was greater than $0.250 \mathrm{~mm}$ in this study, we observed that $\mathrm{ZnOE}$ restorations resulted in only a fraction of the tertiary dentin repair activity of $\mathrm{Ca}(\mathrm{OH})_{2}$ amalgam restorations.

Because of the capacity of $\mathrm{Ca}(\mathrm{OH})_{2}$ to stimulate increased tertiary dentin activity, authors often have recommended its use to line deep cavi- 
ties for pulpal protection. ${ }^{50-52}$ However, our observations show that it is not possible to influence tertiary dentin activity using restorative materials if the RDT is less than $0.251 \mathrm{~mm}$ (Figure 1). Consequently, to restore teeth that have cavity preparations with small RDTs, particularly less than $0.251 \mathrm{~mm}$, we suggest that the cytotoxicity of the material should be a more primary consideration than the tertiary dentin repair response.

The hierarchy of materials in regard to reduced odontoblast density beneath deep cavity preparations was as follows: $\mathrm{Ca}(\mathrm{OH})_{2}, \mathrm{ZnOE}$, resin-based composite bonded to dentin, $\mathrm{ZnPC}$, resin-based composite bonded to enamel and RMGI (Figure 4). Reductions in odontoblast density appear to be correlated to the chemical activity of the liner or restorative material, because some materials are more cytotoxic to pulpal tissue than others. ${ }^{21}$

These observations highlight the importance of avoiding the placement of cytotoxic materials in deep cavity preparations, because unnecessary injury and possible necrosis of underlying vital pulpal tissue must be prevented. Although some reductions in the underlying odontoblast density may be unavoidable to a large extent after the trauma of cavity preparation (Figure 3 ), the placement of resin-based composite bonded to enamel and RMGI within $0.5 \mathrm{~mm}$ of the pulpal tissue appeared to cause reductions of more than 50 percent in the number of odontoblasts (Figure 4). Our RMGI observations in regard to pulpal injuries are in agreement with those of Stanley. ${ }^{53}$ Consequently, we recommend that a thin liner of $\mathrm{Ca}(\mathrm{OH})_{2}$ be applied to the cavity floor of deep preparations before RMGI is placed. This appears to provide pulpal protection from injury and bacterial microleakage.

\section{CONCLUSION}

We have characterized the hierarchy of cavity preparation and restoration variables in relation to pulpal injury and tertiary dentin repair activity. This information can be used to predict pulpal activity after restoration and as an aid in the diagnosis of complications. We recommend that clinicians avoid removing iatrogenic dentin and that they select restorative materials that minimize bacterial microleakage and pulpal injury to ensure the best possible restorative treatment outcomes.

Dr. Murray is a research fellow, Oral Biology, School of Dentistry, The University of Birmingham, St. Chad's Queensway, Birmingham, England, B4 6NN, e-mail "p.e.murray@bham.ac.uk". Address reprint requests to Dr. Murray.
Dr. About is a lecturer, Faculte d'Odontologie, Interface Matrice Extracellulaire Biomateriaux, Marseille, France.

Dr. Franquin is a professor of dentistry, Faculte d'Odontologie, Interface Matrice Extracellulaire Biomateriaux, Marseille, France.

Ms. Remusat is a researcher, Faculte d'Odontologie, Interface Matrice Extracellulaire Biomateriaux, Marseille, France.

Dr. Smith is a professor of oral biology, School of Dentistry, The University of Birmingham, England.

This work was supported by a short-term research program as part of the European COST action B8 on Odontogenesis, and grant 057820 from the Wellcome Research Trust Foundation.

The authors thank the clinicians of Marseille Hospital dental care centers who prepared the cavities and restorations, in particular Dr. J-L. Brouillet, Dr. Y. Miranda and Dr. J-P. Trotebas.

1. Arnst C, Carey J. Biotech bodies. Businessweek July 1998:42-9.

2. Baume LJ, Fiore-Donno G. Response of the human pulp to a new restorative material. JADA 1968;76:1016-22.

3. Suarez CL, Stanley HR, Gilmore HW. Histopathologic response of

the human dental pulp to restorative resins. JADA 1970;80:793-800

4. Brannstrom M, Nyborg H. Pulpal reaction to composite resin restorations. J Prosthet Dent 1972;27:181-9.

5. Goto G, Jordan RE. Pulpal response to composite-resin materials. J Prosthet Dent 1972;28:601-6.

6. Dalleske RL, Stanley HR, Heyde JB. Human pulp response to a new composite system: Vytol composite restorative and bonding agent. Oral Surg Oral Med Oral Pathol 1978;46:418-26.

7. Qvist V, Thylstrup A, Mjör IA. Restorative treatment pattern and longevity of resin restorations in Denmark. Acta Odontol Scand

1986;44:351-6.

8. Mjör IA, Jokstad A, Qvist V. Longevity of posterior restorations. Int Dent J 1990;40:11-7.

9. Maupome G, Sheiham A. Criteria for restoration replacement and restoration life-span estimates in an educational environment. J Oral Rehabil 1998;25:896-901.

10. Burke FJ, Cheung SW, Mjör IA, Wilson NH. Reasons for the placement and replacement of restorations in vocational training practices. Prim Dent Care 1999;6:17-20.

11. Bergenholtz G, Cox CF, Loesche WJ, Syed SA. Bacterial leakage around dental restorations: its effect on the dental pulp. J Oral Pathol 1982;11:439-50.

12. Cox CF. Microleakage related to restorative procedures. Proc

Finn Dent Soc 1992;88(suppl 1):83-93.

13. Bergenholtz G. Pathogenic mechanisms in pulpal disease. J Endod 1990;16:98-101.

14. Suh BI, Cincione FA. All-Bond 2: the fourth generation bonding system. Esthet Dent Update 1992;5:61-6.

15. Kitasako Y, Inokoshi S, Tagami J. Effects of direct pulp capping techniques on short-term response of the mechanically exposed pulp beneath adhesive resin systems. J Dent 1999;27:257-63.

16. Vann WF Jr., Barkmeier WW, Mahler DB. Assessing composite resin wear in primary molars: four-year findings. J Dent Res 1988;67:876-9

17. Tonn EM, Ryge G. Clinical evaluations of composite resin restorations in primary molars: a 4-year follow-up study. JADA 1988;117:603-6

18. Berry TG, Summitt JB, Chung AK, Osborne JW. Amalgam at the new millennium. JADA 1998;129:1547-56.

19. Duke ES. Adhesion and its application with restorative materials. Dent Clin North Am 1993;37:329-40.

20. Shavell HM. The amalgapin technique for complex amalgam restorations. J Calif Dent Assoc 1980;8:48-55.

21. Tsunekawa M, Usami Y, Iwaku M, Setcos JC, Marshall SJ. A new light-activated adhesive cavity liner: an in vitro bond strength and microleakage study. Dent Mater 1992;8:296-8.

22. Donly KJ, Grandgenett C. Dentin demineralization inhibition at restoration margins of Vitremer, Dyract and Compoglass. Am J Dent 1998;11:245-8.

23. Donly KJ, Segura A, Kanellis M, Erickson RL. Clinical performance and caries inhibition of resin-modified glass ionomer cement and amalgam restorations. JADA 1999;130:1459-66.

24. Cox CF. Re-evaluating pulp protection: calcium hydroxide liners vs. cohesive hybridization. JADA 1994;125:823-31.

25. Cox CF, Bergenholtz G, Heys DR, Syed SA, Fitzgerald M, Heys

RJ. Pulp capping of dental pulp mechanically exposed to oral 
microflora: a 1-2 year observation of wound healing in the monkey. J Oral Pathol 1985;14:156-68.

26. Saxe SR, Wekstein MW, Kryscio RJ, et al. Alzheimer's disease, dental amalgam and mercury. JADA 1999;130:191-9.

27. Use survey-1995. Clin Res Associates Newsletter 1995;19(10):4.

28. Murray PE, About I, Lumley PJ, Franquin JC, Remusat M, Smith AJ. Human odontoblast cell numbers after dental injury. J Dent 2000;28:277-85.

29. Murray PE, About I, Lumley PJ, Smith G, Franquin JC, Smith AJ. Postoperative pulpal and repair responses. JADA 2000;131:321-9.

30. Murray PE, Lumley PJ, Ross HF, Smith AJ. Tooth slice organ culture for cytotoxicity assessment of dental materials. Biomaterials 2000;21:1711-21.

31. Federation Dentaire International. Commission on Dental Materials, Instruments, Equipment and Therapeutics. Stanford JW. Recommended standard practices for the biological evaluation of dental materials. Int Dent J 1980;30:140-88.

32. ISO/EN 7405. Preclinical evaluation of biocompatibility of medica devices used in dentistry: test methods for dental materials. Geneva, Switzerland: International Organization for Standardization; 1997.

33. Lillie RD, Fullmer HM. Histopathologic technique and practical histochemistry. 4th ed. New York: McGraw-Hill; 1976.

34. Langeland LK, Guttuso J, Jerome DR, Langeland K. Histologic and clinical comparison of Addent with silicate cements and cold-curing materials. JADA 1966;72:373-85.

35. Hebling J, Giro EM, Costa CA. Human pulp response after an adhesive system application in deep cavities. J Dent 1999;27:557-64.

36. Kitsano Y, Nakajima M, Pereira PN, et al. Monkey pulpal response and microtensile strength beneath a one-application resin bonding system in vivo. J Dent 2000;28:193-8.

37. Tjan AH, Tan DE, Sun JC, Tjan AH. Marginal leakage of amalgam restorations pretreated with various liners. Am J Dent 1997; $10: 284-6$

38. Cox CF, Hafez AA, Akimoto N, Otsuki N, Suzuki S, Tarim B. Biocompatibility of primer, adhesive and resin composite systems on nonexposed and exposed pulps of non-human primate teeth. Am J Dent 1998;11(special issue):S55-63

39. Mertz-Fairhurst EJ, Curtis JW, Ergle JW, Rueggeberg FA, Adair
SM. Ultraconservative and cariostatic sealed restorations: results at year 10. JADA 1998;129:55-66.

40. van Dijken JW. Direct resin composite inlays/onlays: an 11 year follow-up. J Dent 2000;28:299-306.

41. Douglas WH. Clinical status of dentine bonding agents. J Dent 1989;17:209-15.

42. Brannstrom M, Nordenvall KJ. Bacterial penetration, pulpal reaction and the inner surface of Concise enamel bond: composite fillings in etched and unetched cavities. J Dent Res 1978;57:3-10.

43. Vojinovic O, Nyborg H, Brannstrom M. Acid treatment of cavities under resin fillings, bacterial growth in dentinal tubules and pulpal reactions. J Dent Res 1973;52:1189-93.

44. Retief DH, Austin JC, Fatti LP. Pulpal response to phosphoric acid. J Oral Pathol 1974;3:114-22.

45. Stanley HR, Going RE, Chauncey HH. Human pulp response to acid pre-treatment of dentin and to composite restoration. JADA 1975;91:817-25

46. Macko DJ, Rutberg M, Langeland K. Pulpal response to the application of phosphoric acid to dentin. Oral Surg Oral Med Oral Pathol 1978;45:930-46

47. Eriksen HM, Leidal TI. Monkey pulpal response to composite resin restorations in cavities treated with various cleansing agents. Scand J Dent Res 1979;87:309-17.

48. Snuggs HM, Cox CF, Powell CS, White KC. Pulpal healing and dentinal bridge formation in an acidic environment. Quintessence Int 1993;24:501-10.

49. White KC, Cox CF, Kanca J III, Dixon DL, Farmer JB, Snuggs HM. Pulp response to adhesive resin systems applied to acid-etched vital dentin: damp versus dry application. Quintessence Int 1994;25:259-68

50. Foreman PC, Barnes IE. Review of calcium hydroxide. Int Endod J 1990;23:283-97.

51. Leinfelder KF, Lemons JE. Clinical restorative materials and techniques. Philadelphia: Lea \& Febiger; 1988:110.

52. Anusavice KJ, Phillips RW. Phillips' science of dental materials. 10th ed. Philadelphia: Saunders; 1996:552.

53. Stanley HR. Pulpal consideration of adhesive materials. Oper Dent 1992;5(suppl 5):151-64. 